\title{
Dose-dependent changes in neuroinflammatory and arachidonic acid cascade markers with synaptic marker loss in rat lipopolysaccharide infusion model of neuroinflammation \\ Matthew Kellom, Mireille Basselin, Vasken L Keleshian, Mei Chen, Stanley I Rapoport and Jagadeesh S/Rao*
}

\section{Abstract}

Background: Neuroinflammation, caused by six days of intracerebroventricularinfusion of bacterial lipopolysaccharide (LPS), stimulates rat brain arachidonic acid (AA) metabolism. The mølecular changes associated with increased AA metabolism are not clear. We examined effects of a six-day infusion of a low-dose $(0.5 \mathrm{ng} / \mathrm{h})$ and a high-dose (250 ng/h) of LPS on neuroinflammatory, AA cascade, and pre-and)post-synaptic markers in rat brain. We used artificial cerebrospinal fluid-infused brains as controls.

Results: Infusion of low- or high-dose LPS increased brain protein levels of TNFa, and iNOS, without significantly changing GFAP. High-dose LPS infusion upregulated brain protein and mRNA levels of AA cascade markers (cytosolic CPLA $2-I V A$, secretory sPLA $-V$, cyclooxygenase-2 and 5-lipoxygenase), and of transcription factor NF-kB p50 DNA binding activity. Both LPS doses increased CPLA 2 and p38 mitogen-activated protein kinase levels, while reducing protein levels of the pre-synaptic marker, synaptophysin. Post-synaptic markers drebrin and PSD95 protein levels were decreased with high- but not low-dose LPS.

Conclusions: Chronic LPS infusion has differential effects, depending on dose, on inflammatory, AA and synaptic markers in rat brain. Neuroinflammation associated with upregulated brain AA metabolism can lead to synaptic dysfunction.

Keywords: Arachidonic acid, Cytokine, Synapse, Drebrin, Lipopolysaccharide, Synaptophysin, Phospholipase $A_{2}$ Neuroinflammation, NF-kB

\section{Background}

Neuroinflammation has been reported in many progressive neurodegenerative and neuropsychiatric brain illnesses, such as Alzheimer's disease, Parkinson's disease, HIV-1 dementia and bipolar disorder [1-4]. Low-grade neuroinflammation can induce slow progressive cellular and tissue damage, whereas high-grade inflammation is associated with robust cytokine release. Despite its pathophysiologic significance, molecular mechanisms underlying effects of low-grade and high-grade neuroinflammation are not fully understood.

\footnotetext{
* Correspondence: jrao@mail.nih.gov

Brain Physiology and Metabolism Section, National Institute on Aging National Institutes of Health, 9000 Rockville Pike, Bldg. 9, 1S-126, Bethesda, MD, USA
}

Six or 30 days of intracerebroventricular (icv) lowdose bacterial lipopolysaccharide (LPS) $(0.5-1.0 \mathrm{ng} / \mathrm{h})$ infusion in rats produces behavioral deficits, induces amyloid deposits, and activates microglia and astrocytes $[5,6]$. Low-dose LPS infusion in rats increases arachidonic acid (AA, 20:4n-6) turnover in brain phospholipids, brain activities of AA-selective cytosolic $\mathrm{Ca}^{2+}$-dependent phospholipase $\mathrm{A}_{2}\left(\mathrm{CPLA}_{2}\right)$ type IVA and of secretory phospholipase $\mathrm{A}_{2}\left(\mathrm{sPLA}_{2}\right)$ type II, and concentrations of prostaglandin (PG) $\mathrm{E}_{2}, \mathrm{PGD}_{2}$ and thromboxane (TX) $\mathrm{B}_{2}$ metabolites [6-9]. However, net brain cyclooxygenase (COX) activity, COX-1 and COX-2 protein levels, and calcium-independent phospholipase $\mathrm{A}_{2}\left(\mathrm{iPLA}_{2}\right.$-VI) activity are unchanged with low-dose LPS infusion $[6,8]$. Depending on the infusion rate and duration, LPS infusion 
has been reported to activate rat brain microglia and astrocytes, increase expression of the transcription factor nuclear factor-kappa B (NF-kB) and inflammatory cytokines, stimulate microglial inducible nitric oxide synthase activity (iNOS) to produce nitric oxide, and increase brain glutamate $[10,11]$.

A 6-day icv infusion of high-dose LPS (250 ng/h) has been shown to increase activated microglia in the rat thalamus [12], activities of $\mathrm{CPLA}_{2}$-IVA and $\mathrm{SPLA}_{2}$-IIA, and unesterified $\mathrm{AA}$ and $\mathrm{PGE}_{2}$ concentrations in rat brain [8]. The same high-dose LPS infusion for 28 days increased mRNA levels of interleukin-1 beta (IL-1 $\beta$ ) and of tumor necrosis factor-alpha (TNF $\alpha$ ), reduced pyramidal cells in layers II and III of the entorhinal cortex, attenuated long-term potentiation (LTP), and impaired spatial memory in adult rats [10,13].

Synaptic proteins such as synaptophysin, drebrin and post-synaptic density-95 (PSD-95) play important roles in synaptic plasticity. Drebrin is an actin-binding neuron-specific protein [14], abundant within dendritic spines at postsynaptic excitatory synapses [15]. Suppressing drebrin expression reduces spine density and results in the formation of thin immature dendritic spines [16]. Thus, the drebrin-actin complex plays a crucial role in the regulation of dendritic spine morphology. Synaptophysin is a $38-\mathrm{kD}$ glycoprotein localized in presynaptic vesicle membranes. Functions of synaptophysin include docking, fusion, and endocytosis, otherwise known as membrane trafficking [17]. PSD-95 is a neuronal protein that associates with receptors and cytoskeletal elements at synapses, and is involved in regulating the number and size of dendritic spines and developing glutamatergic synapses [18]. Changes in these synaptic markers have been used to evaluate neuronal damage [19].

The impact of low- and high-dose LPS infusion on brain AA cascade, neuroinflammatory and synaptic markers has not been examined consistently. Therefore, we thought of interest to measure effects of the two doses of LPS on AA, neuroinflammatory and synaptic markers in rat brain afterla six-day LPS infusion, compared to infusion of artificial cerebrospinal fluid (aCSF). Based on reported upregulated brain AA metabolism in the LPSinfused rat brain, we hypothesized that 6-day icv infusion of low- and high-dose LPS would increase expression of AA cascade and neuroinflammatory markers, and reduce pre- and post-synaptic markers such as synaptophysin and drebrin, in a dose-dependent manner. An abstract of some of this work has been presented [20].

\section{Methods}

\section{Animals}

The study was conducted in accordance with the National Institutes of Health Guidelines for the Care and Use of Laboratory Animals (NIH Publication No. 86-23), and was approved by the Animal Care and Use Committee of the Eunice Kennedy Shriver National Institute of Child Health and Human Development. Three-month-old male Fischer F344 rats (Taconic Farms, Rockville, MD) $(\mathrm{n}=24)$ were housed in a facility with controlled temperature, humidity, and 12-hour light/dark cycle. Food (Rodent NIH-31 auto 18-4 diet, Zeigler Bros, Gardners, PA) and water were provided ad libitum. The diet contained (as \% of total fatty acid) $20.1 \%$ saturated, $22.5 \%$ monounsaturated, $47.9 \%$ linoleic, $5.1 \% \alpha$-linolenic, $0.02 \%$ AA, $2.0 \%$ eicosapentaenoic, and $2.3 \%$ docosahexaenoic acid [21]

\section{LPS infusion}

Low-dose $(1 \mu \mathrm{g} / \mathrm{ml}$ infused at a rate of $0.5 \mathrm{ng} / \mathrm{h})$ or highdose $(0.5 \mathrm{mg} / \mathrm{ml}$ infused at a rate of $250 \mathrm{ng} / \mathrm{h})$ of LPS was infused icv in rats for 6 days as described previously [6-9]. The rationale for choosing the 6-day infusion period is based on a pilot study performed when measuring AA incorporation into brain at $2,3,4,6,8$, and 10 days of lowdose LPS infusion. The study found no increase in total AA incorporation over control values until day 4 (10-15\% increase) of infusion. Incorporation of AA reached a maximum at day 6 and remained elevated until day 10 [22]. We chose to infuse LPS into the fourth ventricle based on earlier studies that showed activation of microglial cells by such LPS infusion [23] and of unregulated brain AA cascade markers [7-9]. Briefly, the prefilled pump was placed in sterile $0.9 \% \mathrm{NaCl}$ at $37^{\circ} \mathrm{C}$ overnight before surgery to start immediate pumping. aCSF $(140 \mathrm{mmol} / \mathrm{L} \mathrm{NaCl}$, $3.0 \mathrm{mmol} / \mathrm{L} \mathrm{KCl}, 2.5 \mathrm{mmol} / \mathrm{L} \mathrm{CaCl}, 1.0 \mathrm{mmol} / \mathrm{L} \mathrm{MgCl}_{2}$, and $1.2 \mathrm{mmol} / \mathrm{L} \mathrm{NaPO}_{4}, \mathrm{pH} 7.4$ ) or LPS from Escherichia coli (Sigma, Saint Louis, MO; serotype 055:B5; source strain, CDC 1644-70; chemotype, rough type) at a low or high dose was infused into the fourth ventricle through the cannula via an osmotic pump (Alzet, Model 2002, Cupertino, CA). Postoperative care included triple antibiotic ointment applied to the wound; $5 \mathrm{ml}$ of sterile $0.9 \% \mathrm{NaCl}$ was injected subcutaneously to prevent dehydration during recovery. Following 6 days of LPS or aCSF infusion, a rat was anesthetized with an overdose of $\mathrm{CO}_{2}$, and decapitated. The brain was rapidly excised, frozen in 2methylbutane at $-50^{\circ} \mathrm{C}$, and stored at $-80^{\circ} \mathrm{C}$ until use. The whole brain was cut into two hemispheres. One half of the brain was used for preparing cytosolic and nuclear extracts and the other half was used for extracting total RNA. Protein homogenates were prepared from the cerebrum and cerebellum without including the brainstem.

\section{Preparation of cytosolic and nuclear fractions}

Cytosolic and nuclear extracts were prepared from control (aCSF), low- and high-dose LPS-infused rats, as previously described [24]. Briefly, brains were homogenized in $10 \mathrm{mM}$ HEPES, $\mathrm{pH}$ 7.9, $0.1 \mathrm{mM}$ EDTA, $0.1 \mathrm{mM}$ EGTA, $1 \mathrm{mM}$ dithiothreitol (DTT), $10 \mathrm{mM} \mathrm{KCl}$, and a 
protease inhibitor cocktail (Roche, Indianapolis, IN), using a Teflon-glass homogenizer. After adding 0.5\% tergitol type NP-40, five additional strokes of homogenization were performed. The suspension was incubated for $30 \mathrm{~min}$ on ice, and then centrifuged in a microcentrifuge $\left(13,000 \times g, 1 \mathrm{~min}, 4^{\circ} \mathrm{C}\right)$. The resulting supernatant was used as the cytosolic fraction. To the nuclear pellet, solution B (20 mM HEPES, pH 7.9, $1 \mathrm{mM}$ EDTA, $1 \mathrm{mM}$ EGTA, $1 \mathrm{mM}$ DTT, $0.4 \mathrm{M} \mathrm{NaCl}$ ) and a protease inhibitor cocktail (Roche) were added. The samples were mixed and placed on a small rotatory shaker for $30 \mathrm{~min}$, then centrifuged at $13,000 \times g$ for $3 \mathrm{~min}$ at $4^{\circ} \mathrm{C}$. The supernatant containing the proteins from the nuclear extracts was transferred to a fresh tube. Protein concentrations of cytosolic fractions and nuclear extracts were determined using Bio-Rad Protein Reagent (Bio-Rad, Hercules, CA).

\section{Western blot analysis}

Proteins from the cytosolic and nuclear fractions $(65 \mu \mathrm{g})$ were separated on 4-20\% SDS-polyacrylamide gels (PAGE) (Bio-Rad) and then electrophoretically transferred to a nitrocellulose membrane (Bio-Rad). Cytosolic protein blots were incubated overnight in TBS containing 5\% nonfat dried milk and $0.1 \%$ Tween-20, with specific primary antibodies for IL-1 $\beta$ (1:500), TNF $\alpha$ (1:500), glial fibrillary protein (GFAP) (1:1000), CD11b (1:1000), ionized calciumbinding adapter molecule 1Iba-1 (1:1000) (monoclonal), iNOS (1:1000), phosphorylated p38 mitogen-activated protein kinase (MAPK) (1:1000) (R\&D Systems, Minneapolis,

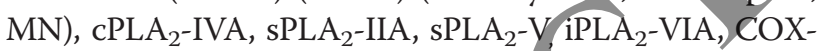
1 (1:1000), COX-2 (1:500), cytochrome P450 epoxygenase (CYP2B1), 5-, 12-, and 15-lipoxygenase (LOX) (1:1000), PSD-95 (1:1000), drebrin (1:1000) (Santa Cruz, Santa Cruz, CA), synaptophysin, (1:1000), and $\beta$-actin $(1: 10,000)$ (Sigma Aldrich, St. Louis, MO). Nuclear blots were incubated overnight in TBS containing 5\% nonfat dried milk and $0.1 \%$ Tween-20, with specific primary antibodies for specificity protein 1 (SP-1) (1:500) and nuclear export factor (NXF) (1:500) (Abcam, Cambridge, MA). Cytosolic blots were incubated with appropriate horseradish peroxidase (HRP)-conjugated secondary antibodies (Bio-Rad) and were visualized using a chemiluminescence reaction (Amersham, Píscataway, NJ) on X-ray film (XAR-5, Kodak, Rochester, NY). Optical densities of immunoblot bands were measured using Alpha Innotech Software (Alpha Innotech, San Leandro, CA) and were normalized to $\beta$ actin (Sigma) to correct for unequal loading. All experiments were carried out with 8 independent samples. Values are expressed as percent of control.

\section{Total RNA isolation and real time RT-PCR}

Total RNA was isolated from half-brains using an RNeasy lipid tissue mini kit (Qiagen, Valencia, CA).
Briefly, tissue was homogenized in Qiagen lysis solution and total RNA was isolated by phenol-chloroform extraction. Complementary DNA was prepared from total RNA using a high-capacity cDNA Archive kit (Applied Biosystems, Foster City, CA). mRNA levels (cPLA ${ }_{2}$-IVA, sPLA $_{2}$-IIA and -V, iPLA ${ }_{2}$-VIA, COX-1, COX-2, 5-, 12-, 15-LOX, cytochrome P450 epoxygenase, drebrin, synaptophysin) were measured by quantitative RT-PCR, using an ABI PRISM 7000 sequence detection system (Applied Biosystems). Specific primers and probes for these markers, purchased from TaqMan $^{\mathrm{R}}$ gene expression assays (Applied Biosystems), consisting of a 20X mix of unlabeled PCR primers and Taqman minor groove binder (MGB) probe (FAM dye-labeled). The fold-change in gene expression was determined by the $\Delta \Delta C_{\mathrm{T}}$ method [25]. Data are expressed as the relative level of the target gene in the LPS-infused rat normalized to the endogenous control ( $\beta$-globulin) andrelative to the control (calibrator). All experiments were carried out in duplicate with 8 control and 8 brain samples from LPS-infused rats and data are expressed as relative expression.

\section{Transcription factor NF-кB p50 and NF-кB p65 activity}

Nuclear extracts were assayed for brain NF-kBp50 and NF-kBp65 activities according to the manufacturer's instructions (Panomics, Freemont, CA). Briefly, $10 \mu \mathrm{g}$ of nuclear extract was preincubated with biotin-labeled NF- $k$ B p50/p65 for $60 \mathrm{~min}$ in a microfuge tube. The labeled oligonucleotide-nuclear protein complexes were transferred to immobilized streptavidin-coated 96-well plates. The bound oligonucleotide protein complex was detected by using a specific primary antibody directed against either NF-kB p50 or p65, followed by addition of HRP-conjugated secondary antibody. Color was developed by adding tetramethylbenzidine substrate, and optical densities were measured at $450 \mathrm{~nm}$. Values $(\mathrm{n}=8)$ are expressed as percent of control.

\section{Statistics}

Data are presented as mean \pm SEM. When three groups were compared (low-dose LPS, high-dose LPS and aCSF control), statistical significance was determined using a one-way ANOVA with Newman-Keuls Multiple Comparison post-hoc test for multiple comparisons between the groups. Statistical significance was set at $\mathrm{p} \leq 0.05$.

\section{Results}

\section{Body weight}

Body weight (grams) was significantly reduced by $9 \%$ and $19 \%$ in low- $(264 \pm 7 ; \mathrm{p}<0.05)$ and high- $(235 \pm 5$; $\mathrm{p}<0.001$ ) dose LPS-infused rats, respectively, compared to control (290 \pm 7 ), as previously reported [8]. 


\section{Brain microglia, astrocyte markers and proinflammatory cytokines}

Six days of high-dose but not low-dose LPS infusion significantly elevated the brain protein level (89\%) of the microglia/macrophage marker CD11b [26], compared to control (Figure 1A). Consistent with that, a significant increase in the protein level of microglia marker Iba- 1 was found in high-dose but not low-dose LPS infused rats (Figure 1B). The astroglial marker GFAP protein level was unchanged in rats infused with either LPS dose compared to control (Figure 1C). Proinflammatory cytokine TNF $\alpha$ protein levels were significantly increased independently of the dose of LPS (332\% and 340\% with lowand high-dose LPS, respectively) (Figure 1D), whereas the IL-1 $\beta$ protein level was unaltered (Figure $1 \mathrm{E}$ ). The protein level of iNOS, a major free radical-generating enzyme in activated microglia [27], was increased significantly by $180 \%$ and $155 \%$, with the low- and high-LPS doses, respectively (Figure 1F). These significant protein changes in CD11b, TNF $\alpha$ and iNOS did not correspond to significant changes in their respective mRNA levels (data not shown). Further, there was no significant difference between low and high-dose LPS infused rats in any neuroinflammatory marker.

\section{Brain arachidonic acid cascade markers}

High-dose LPS significantly increased phosphorylated cPLA ${ }_{2}$-IVA $(120 \%)$ as did low-dose LPS $(60 \%)(\mathrm{p}<0.05)$ compared to control (Figure 2A). The protein and mRNA levels of $\mathrm{CPLA}_{2}$-IVA were significantly elevated by $178 \%$ and 2-fold, respectively, in rats infused with high-dose LPS (Figures $2 \mathrm{~B}$ and $2 \mathrm{C}$ ). High-dose LPS significantly increased phospho-cPLA 2 and CPLA $_{2}$ levels compared to low-dose LPS (Figures $2 \mathrm{~A}$ and $2 \mathrm{~B}$ ). sPLA $\mathrm{A}_{2}-\mathrm{V}$ protein levels were significantly increased by $34 \%$ and $24 \%$ in low- and high-dose LPS-infused rats respectively, compared to control (Figure 2D), but without a significant change in $\mathrm{SPLA}_{2}-\mathrm{V}$ mRNA (Figure 2E). sPLA -IIA and iPLA $_{2}$-VIA protem levels were unaltered.

COX-2 protein (61\%) and mRNA (5-fold) levels were significantly elevated in rats infused with high- but not low-dose LPS compared to controls (Figures 3A and 3B), whereas COX-1protein was unchanged compared to control (Figure 3C). High-dose LPS significantly increased both COX-2 protein and mRNA levels compared to lowdose LPS infused rats (Figures 3A and 3B). Protein (74\%) and mRNA levels of 5-LOX (8-fold) were significantly increased only with the high-dose LPS infusion (Figures 3C and 3D). Protein levels of 12-LOX, 15-LOX and cytochrome $\mathrm{P} 450$ epoxygenase were unaltered by either LPS infusion (Figures $3 \mathrm{~F}$ and $4 \mathrm{~A}-\mathrm{B}$ ).

\section{NF-kB activity and phosphorylated p38 MAPK}

DNA-binding activity of NF- $\mathrm{Bp} 50$ was significantly increased (40\%) in the high-dose LPS-infusion compared to control rats $(\mathrm{p}<0.001)$ (Figure $4 \mathrm{C})$, whereas NF- $\mathrm{kBp} 65$ DNA-binding activity was unaltered (Figure 4D). Highdose LPS significantly increased NF-kBp50 activity

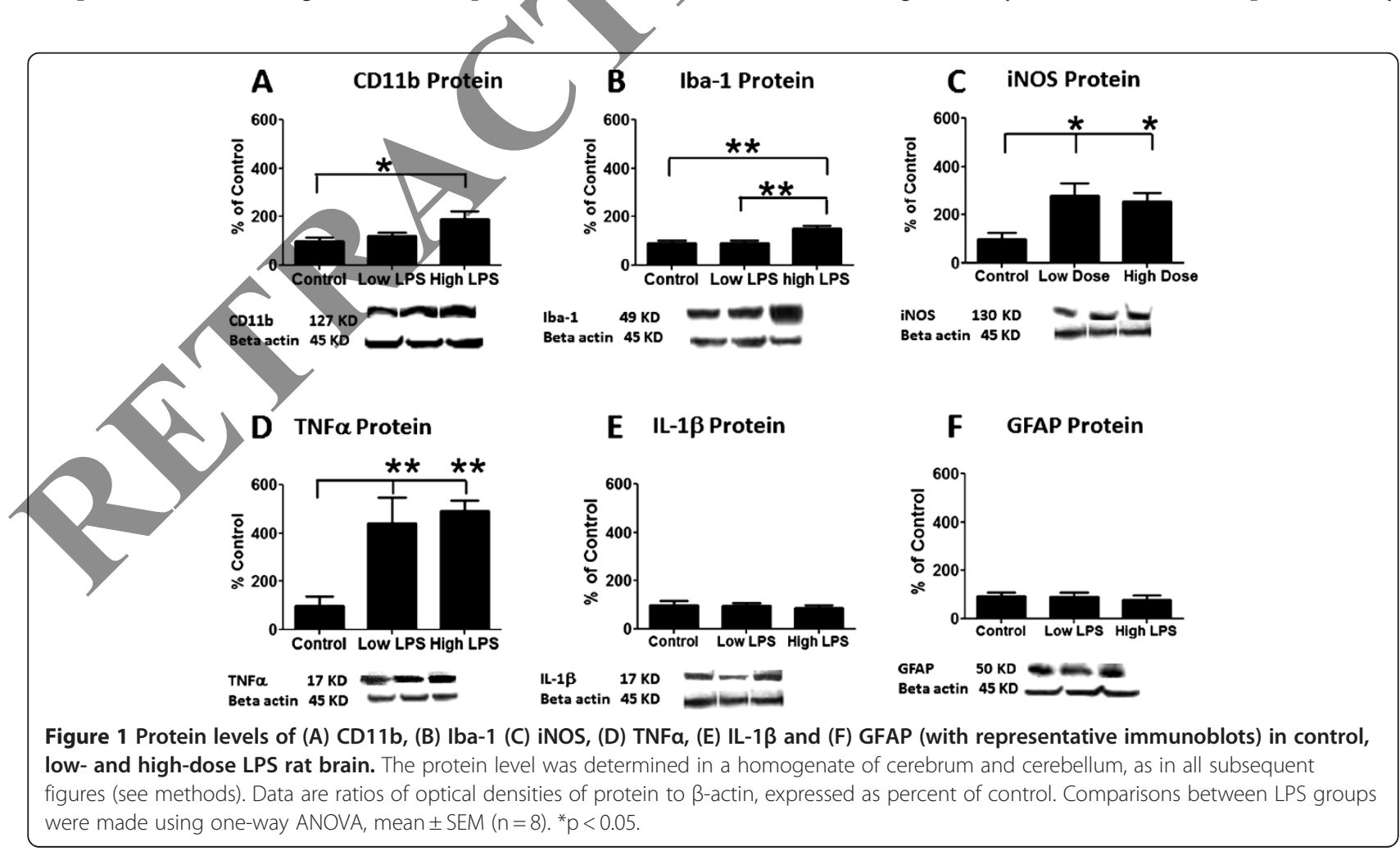




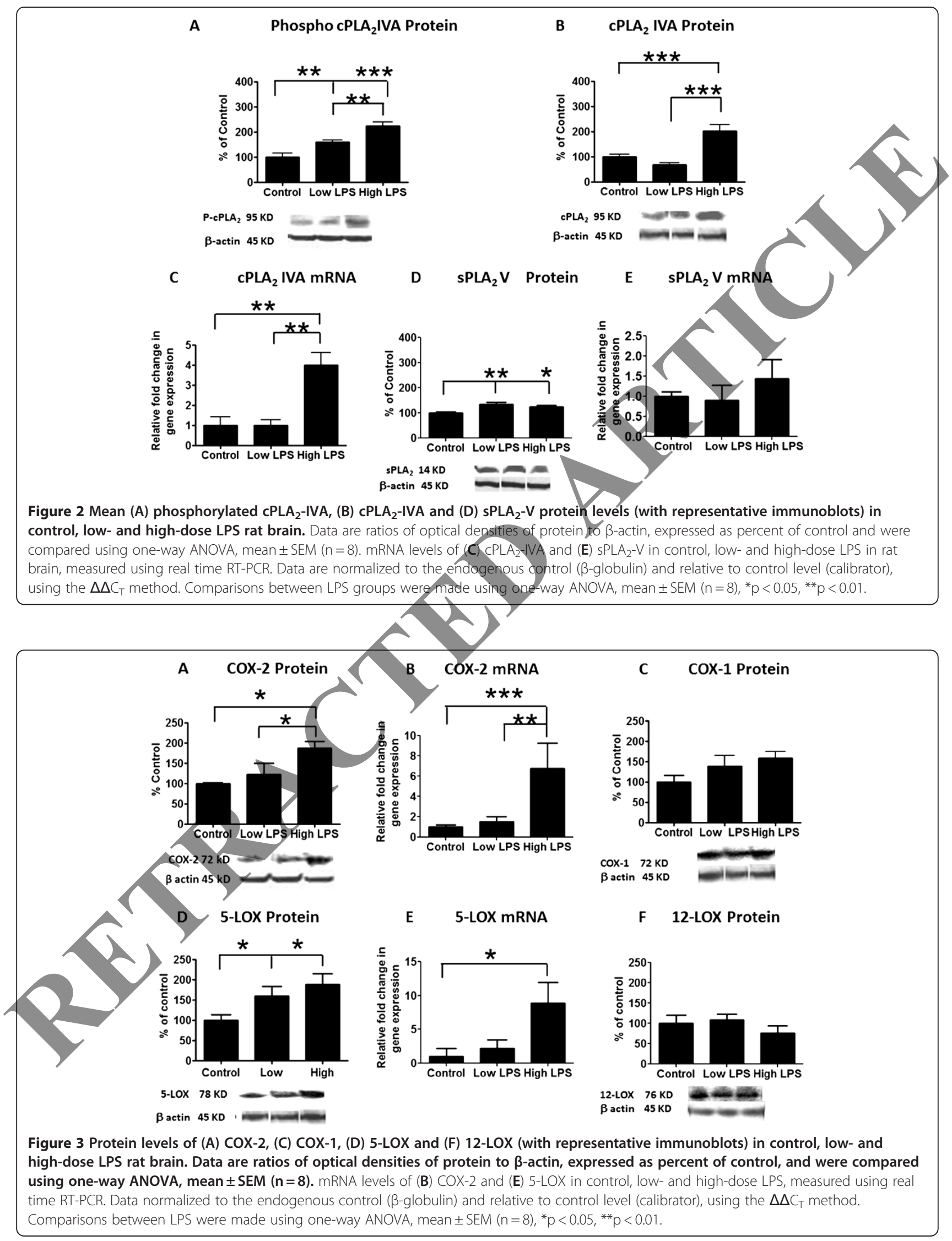


compared to low-dose LPS infused rats (Figures 2A and 2B). Active phosphorylated p38 MAPK was significantly increased by $108 \%$ and $109 \%$ with low- and high-dose LPS infusion, respectively, compared to control (Figure 4E).

\section{Synaptic markers}

Protein levels of the presynaptic marker synaptophysin were significantly decreased by high-dose $(-35 \%)$ and low-dose $(-16 \%)$ LPS, compared to control $(\mathrm{p}<0.05)$ (Figure 5A). However, the mRNA level of synaptophysin was significantly reduced (0.7-fold) only by high-dose LPS (Figure 5B). Postsynaptic marker drebrin protein $(-30 \%)$ and mRNA (-0.6-fold) levels were significantly reduced in high- but not low-dose LPS infused rats compared to control (Figures 5C and 5D). High-dose LPS significantly decreased protein and mRNA levels of synaptophysin and drebrin compared to low-dose LPS infused rats (Figures 5A and D). Further, another marker of post-synaptic marker PSD-95 was significantly decreased by high-dose LPS but not low-dose LPS (Figure 5E). The protein levels of NXF, a transcription factor of drebrin [28], and of SP-1, a constitutive transcription factor of synaptophysin [29], were unaltered (Figures 5F and G).

\section{Discussion}

The present study demonstrates that a 6-day icv infusion of low- or high-dose LPS in unanesthetized rats, compared with aCSF infusion, significantly increased brain levels of AA cascade and neuroinflammatory markers in a dose-dependent manner (Table 1). These changes were associated with decreased levels of pre-and post-synaptic markers in a dose dependent manner as well. Similar changes have been demonstrated in postmortem brain tissue from patients with bipolar disorder, schizophrenia, AIDS and Alzheimer's disease [4,30-35], suggesting that LPS infusion at different pates in rats are reasonable models for understanding interactions of brain AA metabolism, neuroinflammation and synaptic integrity in these progressive human brain diseases, and perhaps for designing treatments for them [8,9,36,37].

Previously, we reported that a 6-day iev infusion of either LPS dose increased CPLA - -IV activity, but that the low-dose infusion did not alter the $\mathrm{CPLA}_{2}$-IV protein level [6-8]. In the present study, although both LPS doses increased phosphorylated $\mathrm{CPLA}_{2}$-IVA and phosphorylated p38 MAPK (linked to activation and phosphorylation of $\mathrm{CPLA}_{2}$ and AA release [38]), only the high-dose induced $\mathrm{mRNA}$ and protein increases of ${ }_{\text {cPLA }}$-IVA. These new data demonstrate that high-dose but not low-dose LPS infusion induced transcriptional level activation. Both doses also increased brain sPLA $_{2}$ activity [6-8], which can be ascribed to upregulated protein levels of $\mathrm{sPLA}_{2}-\mathrm{V}[39,40]$ since $\mathrm{sPLA}_{2}$-IIA protein was unchanged. In contrast, $\mathrm{Ca}^{2+}$-independent docosahexaenoic acid (DHA)-selective iPLA $\mathrm{A}_{2}$-VIA protein and

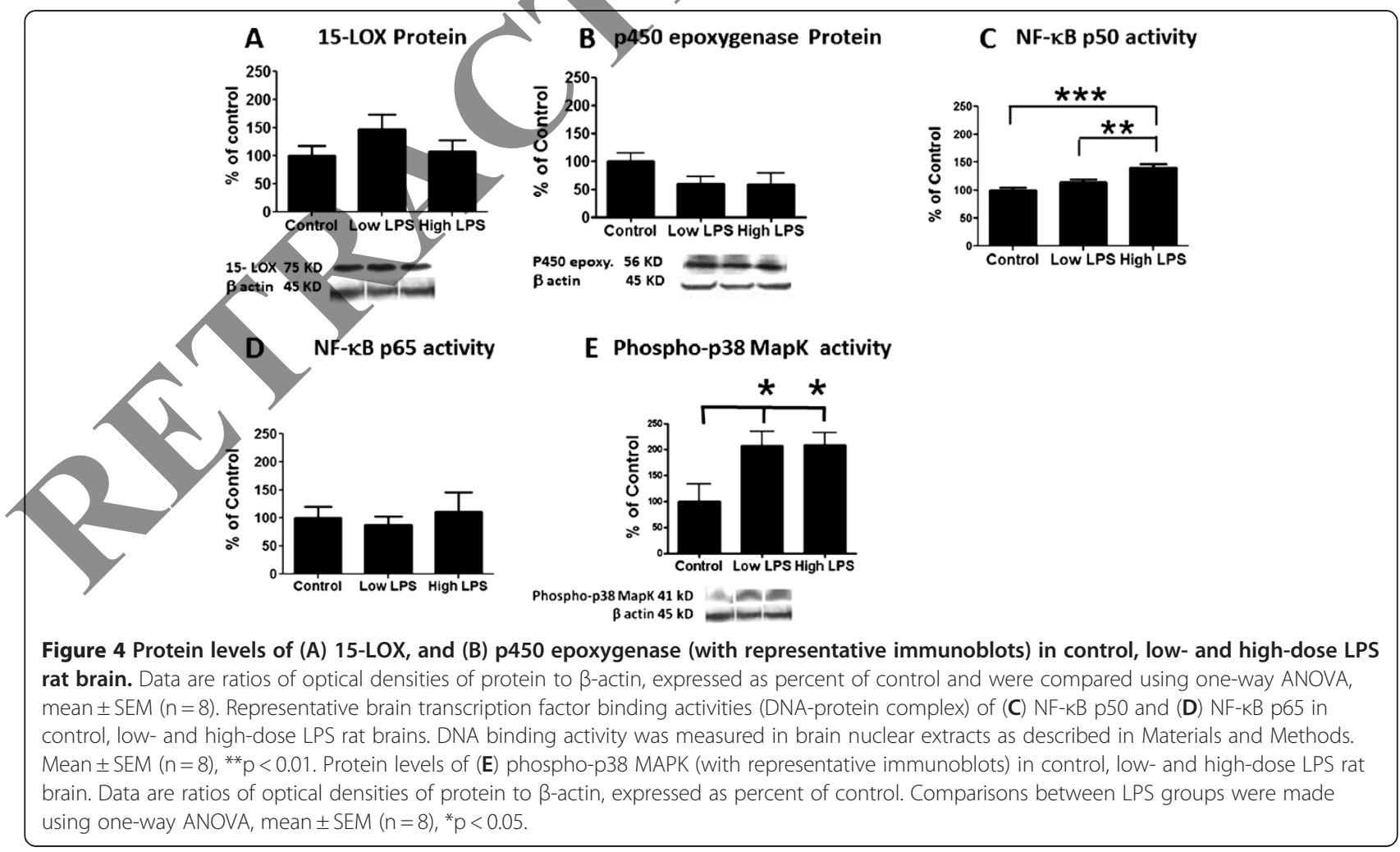




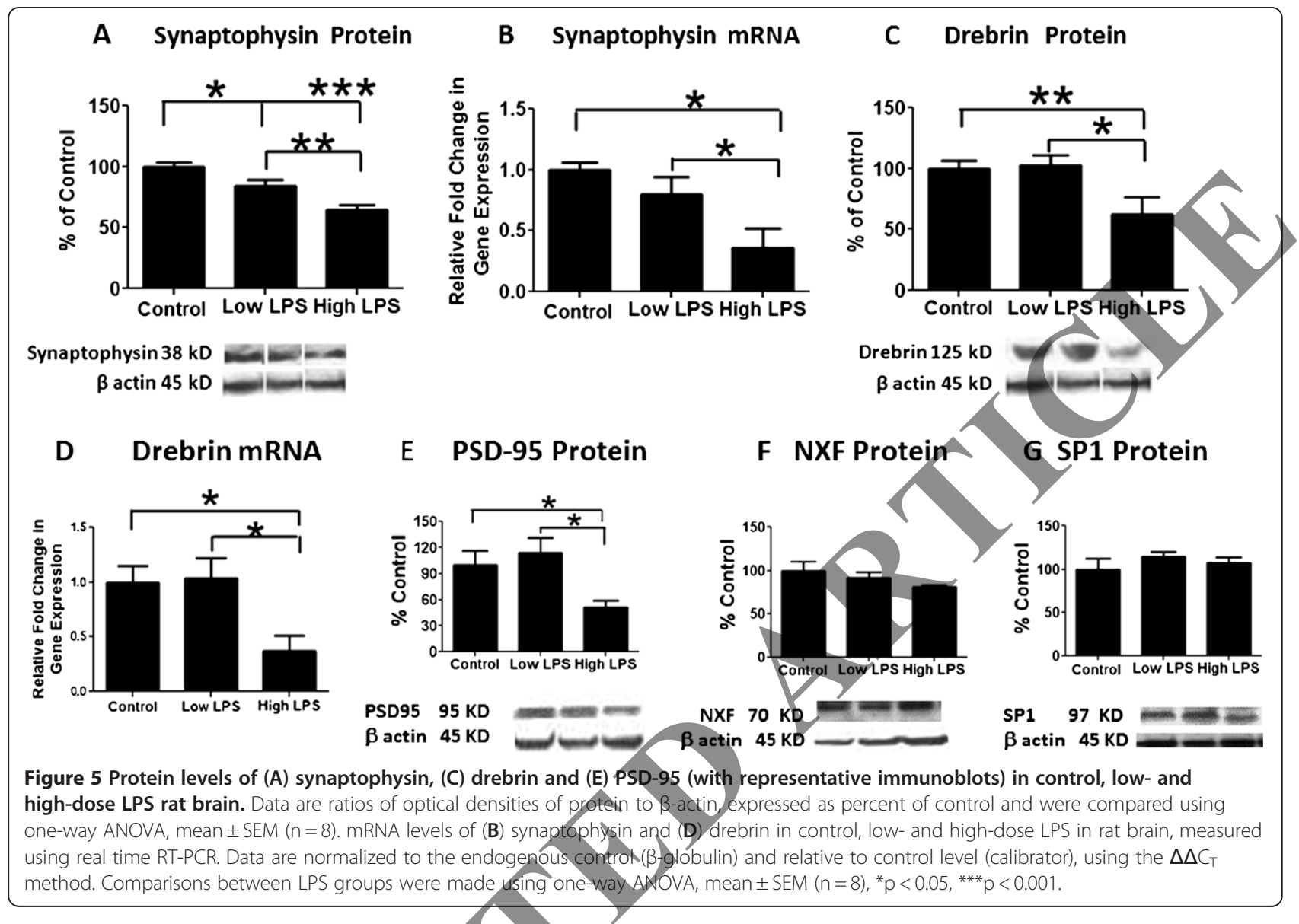

mRNA levels were not significantly altered by either dose of LPS. This is consistent with evidence that neither LPS infusion dose changed the brain unesterified DHA concentration, DHA turnover in brain phospholipids or iPLA 2 -VI activity $[6,8,22,41]$.

The brain $\mathrm{PGE}_{2}$ concentration was elevated in rats infused with both LPS doses, consistent with increased concentration of unesterified AA released by CPLA $_{2}$-IVA and $\mathrm{SPLA}_{2}-\mathrm{V}$ [6-8]. Protein and mRNA levels of COX-2, the rate-limiting enzyme in $\mathrm{PGE}_{2}$ biosynthesis, were upregulated with only the higher dose of LPS, showing a dose-dependent effect. In line with a previous observation, low-dose LPS infusion did not alter the brain COX-2 protein level [6].

LOX and cytochrome P450 epoxygenase convert AA to 5-hydroxyeicosatetraenoic acid (5-HETE)/leukotrienes/ lipoxins and epoxyeicosatrienoic acids, respectively. The high-dose LPS infusion increased 5-LOX protein and mRNA levels, without altering 12- or 15-LOX levels. Concentrations of 12-HETE and 15-HETE remain unchanged with both doses [8]. In this regard, LPS has been reported to induce expression of 5-LOX [42] and the 5-LOXactivating protein (FLAP) via NF- $\mathrm{kB}$-mediated transcriptional mechanisms in mononuclear phagocytes, which is critical for leukotriene synthesis [43]. Another AA cascade marker, cytochrome $\mathrm{P} 450$ epoxygenase, remained unchanged after LPS infusion.

Cell culture studies have shown that two major cytokines, IL-1 $\beta$ and TNF $\alpha$, can induce transcription of $\mathrm{CPLA}_{2}$, $\mathrm{sPLA}_{2}, \mathrm{COX}-2$, and iNOS genes through an NF-kBmediated mechanism [44-46], as NF-kB binding sites are present on the promoter regions of these genes [46-49]. Our study suggesting that increases of $\mathrm{CPLA}_{2}$-IVA, COX-2, and iNOS in high-dose LPS-infused rats were due to elevated levels of TNF $\alpha$ following increased NF-kB p50 activity, was recently supported by in vitro studies [50]. The response was not observed in low-dose LPS infusion. NF$\kappa \mathrm{B}$ p50 also is known to regulate transcription of many proinflammatory genes $[51,52]$. Since p38 MAPK can activate NF- $\mathrm{kB}$ mediated cell signaling [53], the increases found in phosphorylated p38 MAPK (the active form) [54] may be involved in LPS-mediated NF- $k B$ activation. These changes my induce TNF $\alpha$ and COX-2 $[55,56]$. NF-kB also can be activated by other cellular signal transduction factors, such as extracellular signal-regulated kinase (ERK) or c-Jun N-terminal kinase (JNK) [57,58].

Consistent with the increased TNFa level, a proinflammatory cytokine produced by microglia [59], high- 
Table 1 Summary of effects compared to control, 6 days of LPS infusion on neuroinflammatory, AA cascade, and synaptic markers in rat brain

\begin{tabular}{|c|c|c|}
\hline & Low-dose LPS & High-dose LPS \\
\hline \multicolumn{3}{|l|}{ Neuroinflammation } \\
\hline TNFa (protein) & $\uparrow$ & $\uparrow$ \\
\hline CD11b (protein) & No change & $\uparrow$ \\
\hline Iba-1( Protein) & No change & $\uparrow$ \\
\hline iNOS (protein) & $\bar{\uparrow}$ & $\uparrow$ \\
\hline \multicolumn{3}{|l|}{ AA cascade } \\
\hline$\overline{\text { p-cPLA2-IVA (protein) }}$ & $\uparrow$ & $\uparrow$ \\
\hline CPLA2-IVA (protein, mRNA) & No change & $\uparrow$ \\
\hline sPLA2-V (protein) & $\uparrow$ & $\uparrow$ \\
\hline$\overline{C O X-2 ~(p r o t e i n, ~ m R N A) ~}$ & No change & $\uparrow$ \\
\hline 5-LOX (protein, mRNA) & No change & $\uparrow$ \\
\hline \multicolumn{3}{|l|}{ Transcription regulators } \\
\hline NF-kBp50 (activity) & No change & $\uparrow$ \\
\hline p38 MAPK (protein) & $\uparrow$ & $\uparrow$ \\
\hline \multicolumn{3}{|l|}{ Synaptic markers } \\
\hline Synaptophysin (protein) & $\downarrow$ & $\downarrow(+$ mRNA $)$ \\
\hline Drebrin (protein, mRNA) & $\downarrow$ & $\downarrow(+$ mRNA $)$ \\
\hline PSD-95 (protein) & No Change & $\downarrow$ \\
\hline
\end{tabular}

IL-1 $\beta$, GFAP, iPLA2-VI, sPLA2-IIA, COX-1, 12- and 15-LOX, cytochrome P450 epoxygenase, mPGES, NF-kBp65, NFX, and SP-1 were unchanged.

dose but not low-dose LPS increased the microglia/ macrophage marker CD11b, without altering the astroglial marker GFAP. Microglia but not astrocytes express the LPS CD14/toll-like receptor 4 (TLR4) [60], but we cannot rule out localized regional changes in brain GFAP. Indeed, we reported that low-dose LPS increased lectin-reactive microglia in the cerebral ventricular surround, pia mater, and glial membrane of the cortex, and produced morphological changes of GFAP-positive astrocytes in the cortical mantel and areas surrounding the cerebral ventricles [6]. An increase of CD11b with NF-kB-induced activation of COX-2 by high-dose LPS infusion is consistent with the observation that CD11b plays a significant role in the optimal production of COX-2 via NE-kB [56]. Since CD11b integrins originally were identified as LPS receptors [61], our data suggest that high-dose but not low-dose LPS modifies the CD11b receptor. Further, the microglial specific marker [62], Iba- 1 was significantly increased in high-dose compared to low-dose LPS infused rats, suggesting the presence of activated microglia in high-dose LPS infused rats.

Increases in TNF $\alpha$ and iNOS levels and in AA cascade enzyme expression have been implicated in neuronal damage [63] and cognitive-behavioral impairments in rats infused with high doses of LPS [10]. The latter impairments might be due to reduced expression of the postsynaptic dendritic spine actin-regulatory protein drebrin, which is involved in spinogenesis and synaptogenesis [15]. LPS reduced the presynaptic vesicle marker synaptophysin in a dose-dependent manner. The molecular mechanisms by which neuroinflammation downregulate drebrin in rat brain are not clear. Several studies reported that inhibition of p38 MAPK activity prevented cytokine-induced loss of synaptophysin in rat primary cortical neuronal cultures and in an animal model of Alzheimer's disease [64,65]. Similarly, drebrin loss was attributed to p38 MAPK activity in hippocampal cultures [66]. Apart from cytokines, $\mathrm{PGE}_{2}$ is known to activate p38 MAPK in rat primary astrocytes [67]. Both LPS doses increase the $\mathrm{PGE}_{2}$ concentration in rat brain [6-8] and may be involved in activating p38 MAPK. Increased p38 MAPK activity observed in this study may explain the loss of synaptophysin following low- and high-dose LPS infusion. Interestingly, the increased p38 MAPK may not be solely responsible for synaptic loss, because low-dose LPS increased p38 MAPK activity without changing the synaptic proteins. This suggests that other mechanisms are involved regulating the synaptic proteins. Further specific in vitro studies are required to understand synaptic regulation by LPS. Both LPS doses also did not change protein levels of NXF or SP-1, transcription factors for drebrin and synaptophysin, respectively $[28,29]$. The changes in the synaptic markers might be related to post-transcriptional regulation or changes of other transcription factors/kinases $[28,29]$. Consistent with loss of post-synaptic drebrin, the protein level of another postsynaptic marker PSD-95 was decreased in high-dose LPS infused rats compared to controls and low-dose infused rats.

A limitation of current study is that one time point (6 days) was taken to study the effects LPS infusion based on the AA cascade metabolism. This choice was based on a prior study showing that AA incorporation in rat brain with low-dose LPS infusion did not increase until day 4 (10-15\% increase) of infusion, reached a maximum at day 6 and remained elevated until day 10; no difference was evident at day 28 [22]. However, at earlier time points Toll receptors and other pathways are activated [68]. Future studies should aim at earlier and perhaps later time points.

\section{Conclusions}

We demonstrated that 6-day icv LPS infusion dosedependently increased neuroinflammatory and AA cascade markers associated with an increase in phosphorylated p38 MAPK, and decreased synaptic markers (Table 1). Lowdose LPS increased TNF $\alpha$, iNOS, sPLA 2 -V, cPLA ${ }_{2}$-IVA and p38 MAPK phosphorylation, and reduced presynaptic synaptophysin. High-dose LPS upregulated gene expression of AA cascade enzymes via NF- $\mathrm{B}, \mathrm{CD} 11 \mathrm{~b}$, and downregulated postsynaptic drebrin. Targeting these disturbed 
pathways by specific anti-inflammatory drugs and/or CPLA $_{2}$ inhibitors could lead to therapeutic treatments of neuronal damage and behavioral changes associated with neuroinflammation [7-9,69].

\begin{abstract}
Abbreviations
aCSF, Artificial CSF; CPLA 2 , Calcium-dependent cytosolic phospholipase $A_{2 i}$ COX, Cyclooxygenase; GFAP, Glial fibrillary acidic protein;

HETE, Hydroxyeicosatetraenoic acid; IL-1 $\beta$, Interleukin-1 $\beta$; iNOS, Inducible nitric oxide synthase; iPLA $A_{2}$ Calcium-independent phospholipase $A_{2}$; LOX, Lipoxygenase; LPS, Lipopolysaccharide; MAPK, Mitogen-activated protein kinase; NF-kB, Nuclear factor-kappa B; NXF, Nuclear export factor; p, Phosphorylated; mPGES, Membrane PGE synthase; $\mathrm{SPLA}_{2}$, Secretory phospholipase $\mathrm{A}_{2} ; \mathrm{SP}-1$, Specificity protein $1 ;$ TNFa, Tumor necrosis factor a
\end{abstract}

\section{Competing interests}

The authors declare that they have no competing interests.

\section{Authors' contributions}

MK participated in the sacrifice of animals, carried out the molecular biology studies, performed the statistical analysis, and drafted the manuscript. MB wrote the animal protocol, participated in the rat surgery, prepared osmotic pumps, and revised the manuscript. VLK performed Western blot studies. MC performed the surgery. SIR participated in the design of the experimental work and corrected the final version of the manuscript. JSR participated in the design of the experimental work, performed the statistical analysis, drafted the manuscript and wrote its final version. All authors read and approved the final manuscript.

\section{Acknowledgements}

This research was supported entirely by the Intramural Research Program of the National Institute on Aging, National Institutes of Health. We thank the $\mathrm{NIH}$ Fellow Editorial Board for assistance.

Received: 16 December 2011 Accepted: 8 May 2012 Published: 23 May 2012

References

1. Anthony IC, Bell JE: The Neuropathology of HIV/AIDS. Int Rev Psychiatry 2008, 20(1):15-24.

2. Esposito G, Giovacchini G, Liow JS, Bhattacharjee AK, Greenstein D, Schapiro M, Hallett M, Herscovitch P, Eckelman WC, Carson RE, et al: Imaging neuroinflammation in Alzheimer's disease with radiolabeled arachidonic acid and PET. J Nucl Med 2008, 49(9):1414-12421.

3. Nimmo AJ, Vink R: Recent patents in CNS drug discovery: the management of inflammation in the central nervous system. Recent Pat CNS Drug Discov 2009, 4(2):86-9

4. Rao JS, Harry GJ, Rapoport SI, Kim HW: Increased excitotoxicity and neuroinflammatory markers in postmortem frontal cortex from bipolar disorder patients. Mol Psychiatry 2010, 15(4):384-392.

5. Richardson RL, Kim EM, Gardíner T, O'Hare E: Chronic intracerebroventricular infusion of lipopolysaccharide: effects of ibuprofen treatment and behavioural and histopathological correlates. Behav Phirmacol 2005, 16(7):531-541.

Rosenberger TA, Villacreses NE, Hovda JT, Bosetti F, Weerasinghe G, Wine RN, Harry G, Rapoport SI: Rat brain arachidonic acid metabolism is increased by a 6-day intracerebral ventricular infusion of bacterial lipopolysaccharide. J Neurochem 2004, 88(5):1168-1178.

7. Basselin M, Villacreses NE, Lee HJ, Bell JM, Rapoport SI: Chronic lithium administration attenuates up-regulated brain arachidonic acid metabolism in a rat model of neuroinflammation. J Neurochem 2007, 102(3):761-772.

8. Basselin M, Kim HW, Chen M, Ma K, Rapoport SI, Murphy RC, Farias SE: Lithium modifies brain arachidonic and docosahexaenoic metabolism in rat lipopolysaccharide model of neuroinflammation. J Lipid Res 2010, 51(5):1049-1056.

9. Basselin M, Ramadan E, Chen M, Rapoport Sl: Anti-inflammatory effects of chronic aspirin on brain arachidonic acid metabolites. Neurochem Res 2011, 36(1):139-145.
10. Hauss-Wegrzyniak B, Dobrzanski P, Stoehr JD, Wenk GL: Chronic neuroinflammation in rats reproduces components of the neurobiology of Alzheimer's disease. Brain Res 1998, 780(2):294-303.

11. Willard LB, Hauss-Wegrzyniak B, Danysz W, Wenk GL: The cytotoxicity of chronic neuroinflammation upon basal forebrain cholinergic neurons of rats can be attenuated by glutamatergic antagonism or cyclooxygenase2 inhibition. Exp Brain Res 2000, 134(1):58-65.

12. Marriott LK, McGann-Gramling KR, Hauss-Wegrzyniak B, Sheldahl Le, Shapiro RA, Dorsa DM, Wenk GL: Estrogen replacement regimen and brain infusion of lipopolysaccharide differentially alter steroid receptor expression in the uterus and hypothalamus. Endocrine 2007, 32(3):317-328.

13. Hauss-Wegrzyniak B, Wenk GL: Beta-amyloid deposition in the brains of rats chronically infused with thiorphan or lipopolysaccharide: the role of ascorbic acid in the vehicle. Neurosci Lett 2002, 322(2):75-78.

14. Kojima N, Kato Y, Shirao T, Obata K: Núcleotide sequences of two embryonic drebrins, developmentally regulated brain proteins, and developmental change in their mRNAs. Brain Res 1988, 464(3):207-215.

15. Aoki C, Sekino $Y$, Hanamura K, Fujisawa $S$, Mahhadomrongkul $V$, Ren $Y$, Shirao $\mathrm{T}$ : Drebrin $\mathrm{A}$ is a postsynaptic protein that localizes in vivo to the submembranous surface of dendritic sites forming excitatory synapses. J Comp Neurol 2005, 483(4):383-402.

16. Ivanov A, Esclapez M, Pellegrino C, Shirao T, Ferhat L: Drebrin A regulates dendritic spine plasticity and synaptic function in mature cultured hippocampal neurons. JCell Sci 2009, 122(Pt 4):524-534.

17. Evans GJ, Cousin MA Tyrosine phosphorylation of synaptophysin in synaptic vesicle recycling. Biochem Soc Trans 2005, 33(Pt 6):1350-1353.

El-Husseini AE, Schnell E, Chetkovich DM, Nicoll RA, Bredt DS: PSD-95 involvement in maturation of excitatory synapses. Science 2000 290(5495):1364-1368.

Harigaya Y, Shoji M, Shirao T, Hirai S: Disappearance of actin-binding protein, drebrin, from hippocampal synapses in Alzheimer's disease. J Neurosci Res 1996, 43(1):87-92.

20. Kellom M, Basselin M, Chen M, Rapoport SI, Rao JS: Increased neuroinfl ammatory and arachidonic acid cascade markers with synaptic marker loss in lipopolysaccharide infused rats. FASEBJ 2011, 25(650):1-15.

21. DeMar JC Jr, Lee HJ, Ma K, Chang L, Bell JM, Rapoport SI, Bazinet RP: Brain elongation of linoleic acid is a negligible source of the arachidonate in brain phospholipids of adult rats. Biochim Biophys Acta 2006, 176(9):1050-1059.

22. Rosenberger TA, Villacreses NE, Weis MT, Rapoport SI: Rat brain docosahexaenoic acid metabolism is not altered by a 6-day intracerebral ventricular infusion of bacterial lipopolysaccharide. Neurochem Int 2010, 56(3):501-507.

23. Hauss-Wegrzyniak B, Lukovic L, Bigaud M, Stoeckel ME: Brain inflammatory response induced by intracerebroventricular infusion of lipopolysaccharide: an immunohistochemical study. Brain Res 1998, 794(2):211-224.

24. Lahiri DK: An region upstream of the gene promoter for the betaamyloid precursor protein interacts with proteins from nuclear extracts of the human brain and PC12 cells. Brain Res Mol Brain Res 1998, 58(1-2):112-122.

25. Livak KJ, Schmittgen TD: Analysis of relative gene expression data using real-time quantitative PCR and the 2(-Delta Delta $C(T)$ ) Method. Methods 2001, 25(4):402-408.

26. Ford AL, Goodsall AL, Hickey WF, Sedgwick JD: Normal adult ramified microglia separated from other central nervous system macrophages by flow cytometric sorting. Phenotypic differences defined and direct ex vivo antigen presentation to myelin basic protein-reactive CD4+ T cells compared. J Immunol 1995, 154(9):4309-4321.

27. Possel H, Noack H, Putzke J, Wolf G, Sies H: Selective upregulation of inducible nitric oxide synthase (iNOS) by lipopolysaccharide (LPS) and cytokines in microglia: in vitro and in vivo studies. Glia 2000, 32(1):51-59.

28. Ooe N, Saito K, Mikami N, Nakatuka I, Kaneko H: Identification of a novel basic helix-loop-helix-PAS factor, NXF, reveals a Sim2 competitive, positive regulatory role in dendritic-cytoskeleton modulator drebrin gene expression. Mol Cell Biol 2004, 24(2):608-616. 
29. Lietz M, Hohl M, Thiel G: RE-1 silencing transcription factor (REST) regulates human synaptophysin gene transcription through an intronic sequence-specific DNA-binding site. Eur J Biochem 2003, 270(1):2-9.

30. Sa MJ, Madeira MD, Ruela C, Volk B, Mota-Miranda A, Paula-Barbosa MM: Dendritic changes in the hippocampal formation of AIDS patients: a quantitative Golgi study. Acta Neuropathol 2004, 107(2):97-110

31. Griffin DE, Wesselingh SL, MCArthur JC: Elevated central nervous system prostaglandins in human immunodeficiency virus-associated dementia. Ann Neurol 1994, 35(5):592-597.

32. Wesselingh SL, Glass J, McArthur JC, Griffin JW, Griffin DE: Cytokine dysregulation in HIV-associated neurological disease. Adv Neuroimmunol 1994, 4(3):199-206

33. Hatanpaa K, Isaacs KR, Shirao T, Brady DR, Rapoport SI: Loss of proteins regulating synaptic plasticity in normal aging of the human brain and in Alzheimer disease. J Neuropathol Exp Neurol 1999, 58(6):637-643.

34. Abelev BI, Aggarwal MM, Ahammed Z, Amonett J, Anderson BD, Anderson M, Arkhipkin D, Averichev GS, Bai Y, Balewski J, et al: Longitudinal doublespin asymmetry and cross section for inclusive jet production in polarized proton collisions at square root of $s=200 \mathrm{GeV}$. Phys Rev Lett 2006, 97(25):1-25.

35. Kim HW, Rapoport SI, Rao JS: Altered expression of apoptotic factors and synaptic markers in postmortem brain from bipolar disorder patients. Neurobiol Dis 2009, 37(3):596-603.

36. Rapoport SI: Brain arachidonic and docosahexaenoic acid cascades are selectively altered by drugs, diet and disease. Prostaglandins, leukotrienes, and essential fatty acids 2008, 79(3-5):153-156.

37. Cole GM, Frautschy SA: DHA may prevent age-related dementia. J Nutr 2010, 140(4):869-874.

38. Coulon L, Calzada C, Moulin P, Vericel E, Lagarde M: Activation of p38 mitogen-activated protein kinase/cytosolic phospholipase A2 cascade in hydroperoxide-stressed platelets. Free Radic Biol Med 2003, 35(6):616-625.

39. Sawada M, Suzumura A, Hosoya H, Marunouchi T, Nagatsu T: Interleukin- 10 inhibits both production of cytokines and expression of cytokine receptors in microglia. J Neurochem 1999, 72(4):1466-1471.

40. Balsinde J, Shinohara H, Lefkowitz LJ, Johnson CA, Balboa MA, Dennis EA: Group V phospholipase A(2)-dependent induction of cyclooxygenase-2 in macrophages. J Biol Chem 1999, 274(37):25967-25970.

41. Strokin M, Sergeeva M, Reiser G: Docosahexaenoic acid and arachidonic acid release in rat brain astrocytes is mediated by two separate isoforms of phospholipase $\mathrm{A} 2$ and is differently regulated by cyclic AMP and $\mathrm{Ca} 2+$. Br J Pharmacol 2003, 139(5):1014-1022.

42. Czapski GA, Gajkowska B, Strosznajder JB: Systemic administration of lipopolysaccharide induces molecular and morphological alterations in the hippocampus. Brain Res 2010, 1356:85-94.

43. Serio KJ, Reddy KV, Bigby TD: Lipopolysaccháride induces 5-lipoxygenaseactivating protein gene expression in THP-1 cells via a NF-kappaB and C/EBP-mediated mechanism. Am J Physiol Cell Physiol 2005, 288(5):C1125-C1133.

44. Vervoordeldonk MJ, Pineda Torra IM, Aarsman AJ, van den Bosch H: Aspirin inhibits expression of the interleukin-1 beta-inducible group II phospholipase A2. FEBS Lett 1996, 397(1):108-112.

45. Herhandez M, Fuentes L, Fernandez Aviles FJ, Crespo MS, Nieto ML: Secretory phospholipase $A(2)$ elicits proinflammatory changes and upregulates the surface expression of fas ligand in monocytic cells: potential relevance for atherogenesis. Circ Res 2002,

\section{0(1):38-45.}

46. Antonio V, Brouillet A, Janvier B, Monne C, Bereziat G, Andreani M Raymondjean M: Transcriptional regulation of the rat type IIA phospholipase A2 gene by CAMP and interleukin-1beta in vascular smooth muscle cells: interplay of the CCAAT/enhancer binding protein (C/EBP), nuclear factor-kappaB and Ets transcription factors. Biochem $J$ 2002, 368(Pt 2):415-424.

47. Morri $\mathrm{H}$, Ozaki M, Watanabe $Y$ : 5'-flanking region surrounding a human cytosolic phospholipase A2 gene. Biochem Biophys Res Commun 1994, 205(1):6-11.

48. Kleinert $\mathrm{H}$, Schwarz PM, Forstermann U: Regulation of the expression of inducible nitric oxide synthase. Biol Chem 2003, 384(10-11):1343-1364.
49. Tanabe T, Tohnai N: Cyclooxygenase isozymes and their gene structures and expression. Prostaglandins Other Lipid Mediat 2002, 68-69:95-114.

50. Maitra U, Gan L, Chang S, Li L: Low-dose endotoxin induces inflammation by selectively removing nuclear receptors and activating CCAAT/ enhancer-binding protein delta. J Immunol 2011 186(7):4467-4473.

51. Pereira SG, Oakley F: Nuclear factor-kappaB1: regulation and function. Int J Biochem Cell Biol 2008, 40(8):1425-1430.

52. Niederberger E, Schmidtko A, Gao W, Kuhlein H, Ehnert C, Geisslinger G: Impaired acute and inflammatory nociception in mice lacking the p50 subunit of NF-kappaB. Eur J Pharmacol 2007, 559(1):55-60.

53. Campbell J, Ciesielski CJ, Hunt AE, Horwood NJ, Beech JT, Hayes LA, Denys A, Feldmann M, Brennan FM, Foxwell BM: A novel mechanism for TNF-alpha regulation by p38 MAPK: involvement of NF-kappa B with implications for therapy in rheumatoid arthritis. J Immund 2004, 173(11):6928-6937.

54. Doza YN, Cuenda A, Thomas GM, Cohen P, Nebreda AR: Activation of the MAP kinase homologue RK requires the phosphorylation of Thr-180 and Tyr-182 and both residues are phosphorylated in chemically stressed KB cells. FEBS Lett 1995, 364(2):223-228.

55. Nakajima K, Tohyama Y, Kohsaka S, Kuribara T: Protein kinase $C$ alpha requirement in the activation of $\mathrm{p} 38$ mitogen-activated protein kinase, which is linked to the induction of tumor necrosis factor alpha in lipopolysaccharide-stimulated microglia. Neurochem Int 2004, 44(4):205-214.

56. Perera PY, Mayadas TN, Takeuchi O, Akira S, Zaks-Zilberman M, Goyert SM, Vogel SN: CD11b/CD18 acts in concert with CD14 and Toll-like receptor (TLR) 4 to elicit full lipopolysaccharide and taxol-inducible gene expression. Llonmunol 2001, 166(1):574-581.

Bhat NR, Fan F: Adenovirus infection induces microglial activation: involvement of mitogen-activated protein kinase pathways. Brain Res 2002, 948(1-2):93-101.

Waetzig V, Czeloth K, Hidding U, Mielke K, Kanzow M, Brecht S, Goetz M, Lucius R, Herdegen T, Hanisch UK: c-Jun N-terminal kinases (JNKs) mediate pro-inflammatory actions of microglia. Glia 2005, 50(3):235-246.

59. Hanisch UK: Microglia as a source and target of cytokines. Glia 2002, 40(2):140-155.

60. Lehnardt S, Lachance $C$, Patrizi S, Lefebvre S, Follett PL, Jensen FE Rosenberg PA, Volpe JJ, Vartanian T: The toll-like receptor TLR4 is necessary for lipopolysaccharide-induced oligodendrocyte injury in the CNS. J Neurosci 2002, 22(7):2478-2486.

61. Wright SD, Jong MT: Adhesion-promoting receptors on human macrophages recognize Escherichia coli by binding to lipopolysaccharide. J Exp Med 1986, 164(6):1876-1888.

62. Ito D, Imai Y, Ohsawa K, Nakajima K, Fukuuchi Y, Kohsaka S: Microgliaspecific localisation of a novel calcium binding protein, Iba1. Brain Res Mol Brain Res 1998, 57(1):1-9.

63. Block ML, Hong JS: Microglia and inflammation-mediated neurodegeneration: multiple triggers with a common mechanism. Prog Neurobiol 2005, 76(2):77-98

64. Li Y, Liu L, Barger SW, Griffin WS: Interleukin-1 mediates pathological effects of microglia on tau phosphorylation and on synaptophysin synthesis in cortical neurons through a p38-MAPK pathway. J Neurosci 2003, 23(5):1605-1611.

65. Munoz L, Ralay Ranaivo H, Roy SM, Hu W, Craft JM, McNamara LK, Chico LW, Van Eldik L, Watterson DM: A novel p38 alpha MAPK inhibitor suppresses brain proinflammatory cytokine up-regulation and attenuates synaptic dysfunction and behavioral deficits in an Alzheimer's disease mouse model. J Neuroinflammation 2007, 4:21.

66. Maezawa I, Nivison M, Montine KS, Maeda N, Montine TJ: Neurotoxicity from innate immune response is greatest with targeted replacement of E4 allele of apolipoprotein E gene and is mediated by microglial p38MAPK. FASEB J 2006, 20(6):797-799.

67. Fiebich BL, Schleicher S, Spleiss O, Czygan M, Hull M: Mechanisms of prostaglandin E2-induced interleukin-6 release in astrocytes: possible involvement of EP4-like receptors, p38 mitogen-activated protein kinase and protein kinase C. J Neurochem 2001, 79(5):950-958.

68. Goralski KB, Abdulla D, Sinal CJ, Arsenault A, Renton KW: Toll-like receptor-4 regulation of hepatic Cyp3a11 metabolism in a mouse model 
of LPS-induced CNS inflammation. Am J Physiol Gastrointest Liver Physiol 2005, 289(3):G434-G443.

69. Hauss-Wegrzyniak B, Willard LB, Del Soldato P, Pepeu G, Wenk GL:

Peripheral administration of novel anti-inflammatories can attenuate the effects of chronic inflammation within the CNS. Brain Res 1999, 815(1):36-43.

doi:10.1186/1471-2202-13-50

Cite this article as: Kellom et al:: Dose-dependent changes in

neuroinflammatory and arachidonic acid cascade markers with synaptic marker loss in rat lipopolysaccharide infusion model of neuroinflammation. BMC Neuroscience 2012 13:50.

\section{Submit your next manuscript to BioMed Central and take full advantage of:}

- Convenient online submission

- Thorough peer review

- No space constraints or color figure charges

- Immediate publication on acceptance

- Inclusion in PubMed, CAS, Scopus and Google Scholar

- Research which is freely available for redistribution 